\title{
Evaluation of relative intake of fatty acids according to the Northern Sweden FFQ with fatty acid levels in erythrocyte membranes as biomarkers
}

\author{
Maria Wennberg ${ }^{1,2, *}$, Bengt Vessby ${ }^{3}$ and Ingegerd Johansson ${ }^{4,5}$ \\ 'Department of Medicine, Skellefteå Hospital, Skellefteå, Sweden: ${ }^{2}$ Department of Public Health and Clinical \\ Medicine, Occupational Medicine, Umeå University, 90187 Umeå, Sweden: ${ }^{3}$ Department of Public Health and \\ Caring Sciences, Uppsala University, Uppsala, Sweden: ${ }^{4}$ Department of Nutritional Research, Umeå University, \\ Umeå, Sweden: ${ }^{5}$ Department of Odontology, Umeå University, Umeå, Sweden
}

Submitted 19 December 2007: Accepted 18 November 2008: First published online 15 January 2009

\begin{abstract}
Objective: To evaluate the validity of the Northern Sweden eighty-four-item FFQ to estimate intake of fatty acids relative to $24 \mathrm{~h}$ diet recalls (24-HDR) and fatty acids in erythrocyte membranes.

Design: Participants, randomly recruited from the population-based Västerbotten Intervention Project, answered the eighty-four-item FFQ. During the following year each participant carried out ten 24-HDR. Intake of fatty acids measured by the FFQ was compared with intake by the 24-HDR and fatty acid levels in erythrocytes.

Setting: The county of Västerbotten in northern Sweden.

Subjects: Ninety-six men and ninety-nine women.

Results: Spearman correlation coefficients $\left(r_{\mathrm{s}}\right)$ between intakes of the fatty acids $14: 0,15: 0,16: 0,17: 0,18: 2 n-6,18: 3 n-3,20: 5 n-3$ and $22: 6 n-3$ estimated by the FFQ and the 24-HDR were all significant and ranged from $0 \cdot 29(22: 6 n-3$ in men and women) to $0 \cdot 60$ (16:0 in men), whereas significant correlations between FFQ-estimated intake and erythrocyte membrane content were only seen for milk fatty acids $14: 0,15: 0$ and $17: 0\left(r_{\mathrm{s}}=0 \cdot 23-0 \cdot 34\right)$ and fish fatty acids $20: 5 n-3$ and $22: 6 n-3\left(r_{\mathrm{s}}=0 \cdot 42-0 \cdot 51\right)$.

Conclusion: The Northern Sweden eighty-four-item FFQ gives a satisfactory estimate of the intake of fish fatty acids (20:5n-3 and $22: 6 n-3)$ and milk fatty acids ( $15: 0$ and $17: 0$ ), whereas its validity for fatty acids $18: 2 n-6$ and $18: 3 n-3$, derived mainly from vegetable oils, cannot be shown.
\end{abstract}

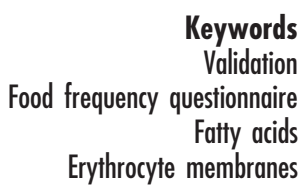

Self-administered FFQ are often used to measure food or nutrient intake in epidemiological studies at costs that are reasonable $\mathrm{e}^{(1-3)}$. A semi-quantitative FFQ has been used to study dietary intake in the population of the two northern-most counties in Sweden (Norrbotten and Västerbotten). The FFQ is used in the population-based Västerbotten Intervention Project (VIP) and nested Northern Sweden Health and Disease studies (NSHD), and data obtained with this FFQ are part of the global cohort for the prospective European Prospective Investigation into Cancer and Nutrition (EPIC) ${ }^{(4)}$. The FFQ is also used in the Northern Sweden WHO MONICA (Multinational Monitoring of Trends and Determinants in Cardiovascular Disease) studies ${ }^{(5)}$. Thus, several nested prospective cohort and case-control studies have used this FFQ to investigate various aspects of dietary intake ${ }^{(6-10)}$, and others are planned for the future.
Diet intake measurements by FFQ, similarly to other diet intake instruments, suffer from systematic and random errors varying with design, procedure and study population. The relative validity of the Northern Sweden FFQ to measure energy, macronutrients and some micronutrients has been evaluated against intakes recorded with ten repeated $24 \mathrm{~h}$ diet recalls (24-HDR) and the biological marker serum $\beta$-carotene in a random sub-sample of the VIP study population. The relative validity of the FFQ was found to be similar to that of other FFQ used in prospective studies on diet and disease, e.g. the correlation coefficients between the FFQ and the 24-HDR for energy and fat estimates were between 0.45 and $0.62^{(11)}$.

The aim of the present study was to extend the previous validation by evaluating fatty acid intake, as measured by the Northern Sweden eighty-four-item FFQ, in relation to fatty acid intake measured by repeated 24-HDR and levels 
of fatty acids in erythrocyte membranes in the same study group as in the basic validation study.

\section{Methods and material}

\section{Study population}

A stratified random subsample of individuals attending the ongoing $\mathrm{VIP}^{(12)}$ in 1992 were asked by mail to participate in the study. Out of a total of 246 individuals invited, forty-three gave a negative response because they could not find the free time to participate in the study. Thus 102 men and 101 women, equally distributed over the ages 30, 40, 50 and 60 years, consented to participate. The participants were recruited in equal proportions from the coastal (more urban) and the inland/mountain (more rural) areas of the county of Västerbotten.

The study was approved by the Ethics Committee for Human Experiments at Umeå University, Sweden.

\section{FFQ (test method)}

The participants were requested to complete an eightyfour-item self-administered FFQ immediately before initiation of the 24-HDR period (in the first quarter of 1993, FFQ1) and a second identical set at the end (in the first quarter of 1994, FFQ2). In the current study FFQ1 was used. The FFQ was designed to be semi-quantitative and optically readable for data input. Frequencies of consumption of eighty-four food items were reported on an increasing, nine-level scale, including: never, a couple of times a year, 1-3 times per month, once a week, 2-3 times a week, 4-6 times a week, once a day, 2-3 times a day, and 4 or more times a day. The questionnaire included eight questions on the frequency of consumption of various types of fats used for spreading on bread or cooking, nine on milk and other dairy products, eight on bread and cereals, ten on fruit, greens and root vegetables, and nine on soft drinks and sugar-containing snacks. Five questions on spirits, wine and beer consumption were included in a list of beverages. Twentynine of the remaining thirty-five questions recorded intake of potato, rice, pasta, meat and fish, and six varied items such as salty snacks, coffee, tea and juice. The respondents indicated their average portion of (i) potato/ pasta/rice, (ii) vegetables and (iii) meat/fish by comparing with four colour photographs illustrating four plates with increasing portion sizes of potato, vegetables and meat. For the other food items, we assumed a standard portion size value (see below). The questionnaires were returned by mail, and the interviewer reviewed it and resolved any ambiguities by telephone.

The reported frequencies of consumption were converted to number of intakes per day. Energy, nutrient and fatty acid $(14: 0,16: 0,18: 2 n-6,18: 3 n-3,20: 5 n-3$ and $22: 6 n-3)$ intakes were calculated by multiplying the frequency by the portion size content according to the
'PC-kost 1995' food composition database (National Food Administration, Uppsala, Sweden). This database is based on analyses of foods from the years preceding 1995. Portion sizes used were either: (i) as indicated by the photographs; (ii) natural portion sizes, such as an apple; or (iii) average portion sizes for gender and age ${ }^{(11)}$. Intakes of 15:0 and 17:0, which are not given in the National Food Administration database, were estimated from the total fat intake from dairy products, i.e. $1 \cdot 05 \mathrm{~g}$ of $15: 0$ and $0 \cdot 61 \mathrm{~g}$ of $17: 0$ per $100 \mathrm{~g}$ milk fat $^{(13)}$.

\section{$24 \mathrm{~b}$ diet recalls (reference method)}

Because many participants lived a considerable distance from the research centre in Umeå, 24-HDR interviews were conducted by telephone ${ }^{(14,15)}$. The interviews were done by nine trained interviewers; all interviewers had an academic education in nutrition, had participated in nutritional research previously, and were trained to structure the interviews in a standardized fashion. Intakes of food, beverages and supplements during the preceding $24 \mathrm{~h}$ were recorded at ten unannounced occasions per subject. The 24-HDR were equally dispersed over the year and covered all weekdays. The estimation of food portions was facilitated by the use of a booklet with fullsize portion size pictures (National Food Administration $\left.^{(16,17)}\right)$, mailed in advance to the participants. These pictures included five options for portions of food on plates, five options for spread on a knife, and a set of schematic drawings ( $n$ 35) to indicate thickness and sizes of various types of food items. Standard household measures were used for the estimation of portion sizes of food items not included in the booklet. Daily energy, fat and fatty acid intakes were calculated (Mat's, Rudans Lättdata, Sweden) employing the 'PC-kost 1995' database (National Food Administration). Milk fatty acids 15:0 and 17: 0 were calculated as described by Wolk et al. ${ }^{(13)}$.

\section{Determination of fatty acid composition}

The erythrocyte fraction was separated from blood samples drawn from the subjects when they attended the VIP screening in 1992. Venous blood samples were drawn without stasis into evacuated tubes after a minimum of $4 \mathrm{~h}$ of fasting. Erythrocytes, buffy coat and plasma were separated by centrifugation at $1500 \mathrm{~g}$ for $15 \mathrm{~min}$, and aliquots were stored at $-80^{\circ} \mathrm{C}$ until used ${ }^{(7)}$.

The fatty acid analyses were performed at the Unit for Clinical Nutrition Research, Department of Public Health and Caring Sciences, Uppsala University, Sweden as described previously ${ }^{(18)}$. Briefly, after thawing, washing and addition of methanol, fatty acids from $0.5 \mathrm{ml}$ erythrocytes were extracted with chloroform $(5 \mathrm{ml})$ containing 0.005\% butylated hydroxytoluene (BHT) as antioxidant. After extraction for $1-4$ days at $4^{\circ} \mathrm{C}$, the chloroform phase was evaporated to dryness under nitrogen. Sulfuric acid in methanol was added and samples were left overnight for transmethylation. Thereafter, water was added and 
methyl esters were extracted into petroleum ether with BHT, the phase was separated by centrifugation, and methyl esters were redissolved in hexane. Then fatty acid methyl esters were separated by GLC. The fatty acids were identified by comparing the retention time of each peak with those of the Nu Check Prep fatty acid methyl ester standards (Elysian, MN, USA). The purity of these standards is greater than $99 \%$. Fatty acid composition of erythrocyte membranes was expressed as the percentage of each fatty acid relative to the total sum of fatty acids. Values below detectable level were set to the lowest observed value of each.

\section{Final participation rate and handling of missing values}

Six participants completed fewer than three 24-HDR and two more did not return the baseline FFQ; these participants were excluded. Thus, ninety-six men and ninetynine women completed ten 24-HDR and the baseline FFQ. These 195 participants represented $79 \%$ of those invited to the study. None of the respondents had left more than ten questions unanswered in the FFQ. The missing answers were present mainly within food groups with several alternative items where one of the items was eaten frequently, such as in the list of milk products or types of fats for bread or cooking. Missing values in the FFQ were therefore interpreted as never being eaten. None of the participants had unreasonably low or high estimated energy intake, i.e. $\pm 3 \mathrm{sD}$, which had been set as exclusion criterion. Data on all fatty acids in erythrocytes were missing for eight men and seven women. In addition, data on 18:3n-3 were missing from two men and one woman. The latter three subjects remained in the analyses because 18:3n-3 makes up a small proportion in erythrocytes and does not affect the proportions of other fatty acids significantly. Thus, eighty-eight men and ninety-two women contributed information on both dietary intake and erythrocyte levels of fatty acids. Subjects with missing data on fatty acids in erythrocytes were retained in the study because information on dietary data was available.

\section{Statistical analyses}

The SPSS statistical software package version 11.5 (SPSS Inc., Chicago, IL, USA) was used for statistical analyses. All evaluations were done separately for men and women, because dietary measurement error profiles and transformation of fatty acids differ between men and women ${ }^{(19)}$. Fatty acid content in erythrocytes is expressed as a percentage of the total fat fraction. To match this, dietary fatty acid intakes are expressed both as absolute $(\mathrm{g} / \mathrm{d})$ and relative $(\mathrm{g} / 100 \mathrm{~g}$ fat $)$ intakes. Relative data for intakes are used for analyses involving erythrocyte membrane data. Geometric mean intakes and 95\% confidence intervals were calculated for fatty acid intake and erythrocyte content, as well as for ratios between intakes for the two dietary methods. Correlations between fatty acid intakes according to the two registration methods and between intakes and levels in erythrocytes were computed with Spearman's rank correlation, because several of the variables were not normally distributed. Ratios of geometric means with $95 \%$ confidence intervals were calculated between the two dietary methods. All tests were two-sided and $P \leq 0.05$ was considered statistically significant.

\section{Results}

\section{Comparison of fatty acid intakes estimated from the FFQ and $24 \mathrm{~b}$ diet recalls}

The ability of the FFQ to rank individuals by fatty acid intake was compared with that of the 24-HDR reference method for absolute and relative intakes, respectively, by Spearman correlations. For all evaluated fatty acids, both absolute ( $\mathrm{g} / \mathrm{d}$, Table 1$)$ and relative $(\mathrm{g} / 100 \mathrm{~g}$ fat, Table 2$)$ intakes measured by the FFQ correlated positively with intakes measured by the 24-HDR reference method. All correlations were statistically significant. The correlation coefficients ranged from $0 \cdot 29(22: 6 n-3$ in men and women) to $0 \cdot 60$ (16:0 in men) for absolute intakes (Table 1) and from $0 \cdot 21$ ( $18: 3 n-3$ in men) to $0 \cdot 45$ (14:0 in men, $15: 0$ in women, $17: 0$ in women and $18: 2 n-6$ in women) for relative intakes (Table 2). The ratios between intakes measured by the two recording methods showed that recorded intake was significantly lower for most fatty acids $(\mathrm{g} / \mathrm{d})$ when estimated with the FFQ compared with the 24-HDR (14:0, 15:0 and 16:0 (women); 17:0, $18: 2 n-6,18: 3 n-3$ and $22: 6 n-3$ (men); Table 1). Similarly, estimated intakes expressed as $\mathrm{g} / 100 \mathrm{~g}$ fat were significantly lower by the FFQ than by the 24-HDR for many fatty acids $(15: 0,17: 0,18: 2 n-6,18: 3 n-3$ and $22: 6 n-3$ (men)). The exceptions were that FFQ-recorded intakes $(\mathrm{g} / 100 \mathrm{~g})$ for $20: 5 n-3$ and $22: 6 n-3$ (women) were higher than 24-HDR intakes (Table 2).

\section{Comparison of fatty acid intakes estimated from the FFQ or $24 \mathrm{~b}$ diet recalls and levels in erythrocytes}

Relative fatty acid levels in erythrocyte membranes correlated positively, and statistically significantly (both sexes), with estimated intakes from both the FFQ and the 24-HDR for 15:0, 20:5n-3 and 22:6n-3 (g/100 g total fat; Table 3). In addition, FFQ-estimated intakes correlated positively, and statistically significantly, with levels in erythrocyte membranes for 14:0 (men) and 17:0, whereas a negative correlation was found for $18: 3 n-3$ (men). Accordingly, estimated intakes from the 24-HDR correlated positively, and statistically significantly, with levels in erythrocytes for 14:0, 16:0 (men) and 17:0 (women; Table 3). Neither FFQ nor 24-HDR estimated intakes correlated positively with erythrocyte levels of 18:2n-6 or $18: 3 n-3$ (neither separate nor combined). The statistically significant correlation coefficients ranged 
Table 1 Absolute fatty acid intake $(\mathrm{g} / \mathrm{d})$ measured by the FFQ and ten repeated $24 \mathrm{~h}$ dietary recalls (24-HDR) in ninety-six men and ninetynine women from Västerbotten County, northern Sweden

\begin{tabular}{|c|c|c|c|c|c|c|c|c|}
\hline & \multirow[b]{3}{*}{ Gender } & \multicolumn{4}{|c|}{ Absolute intake ( $\mathrm{g} / 100 \mathrm{~g}$ fat) } & & & \multirow{3}{*}{$\begin{array}{c}\text { Spearman correlatior } \\
\text { coefficient } \\
\text { FFQ v. } 24-H D R\end{array}$} \\
\hline & & \multicolumn{2}{|c|}{ FFQ } & \multicolumn{2}{|c|}{ 24-HDR } & \multicolumn{2}{|c|}{ Intake ratio FFQ:24-HDR } & \\
\hline & & Mean & $95 \% \mathrm{Cl}$ & Mean & $95 \% \mathrm{Cl}$ & Mean & $95 \% \mathrm{Cl}$ & \\
\hline \multirow[t]{2}{*}{$14: 0$} & Men & $3 \cdot 6$ & $3 \cdot 2,3 \cdot 9$ & $3 \cdot 8$ & $3 \cdot 5,4 \cdot 2$ & 0.95 & $0.85,1 \cdot 00$ & $0.56^{\star \star \star}$ \\
\hline & Women & $2 \cdot 7$ & $2 \cdot 5,2 \cdot 9$ & $2 \cdot 9$ & $2 \cdot 7,3 \cdot 2$ & 0.93 & $0.85,0.99$ & $0 \cdot 51^{\star \star *}$ \\
\hline \multirow[t]{2}{*}{$15: 0$} & Men & 0.23 & $0 \cdot 20,0.26$ & 0.29 & $0.26,0.32$ & 0.79 & $0.69,0.87$ & $0.50^{\star \star \star}$ \\
\hline & Women & $0 \cdot 17$ & $0 \cdot 15,0 \cdot 19$ & 0.22 & $0 \cdot 20,0.24$ & 0.77 & $0 \cdot 68,0.85$ & $0.52^{\star \star \star}$ \\
\hline \multirow{2}{*}{$16: 0$} & Men & 16 & 15,17 & 17 & 16,18 & 0.94 & $0 \cdot 87,1 \cdot 00$ & $0 \cdot 60^{\star \star *}$ \\
\hline & Women & 12 & 11,13 & 13 & 12,14 & 0.92 & $0.86,0.98$ & $0.51^{\star \star \star}$ \\
\hline \multirow{2}{*}{$17: 0$} & Men & 0.13 & $0 \cdot 11,0 \cdot 15$ & 0.17 & $0 \cdot 15,0 \cdot 19$ & $0 \cdot 76$ & $0.69,0.87$ & $0.50^{\star \star \star *}$ \\
\hline & Women & $0 \cdot 10$ & $0 \cdot 09,0 \cdot 11$ & $0 \cdot 13$ & $0 \cdot 12,0 \cdot 14$ & $0 \cdot 77$ & $0 \cdot 68,0.85$ & $0 \cdot 52^{\star \star \star}$ \\
\hline \multirow[t]{2}{*}{$18: 2 n-6$} & Men & $7 \cdot 2$ & $6 \cdot 6,7 \cdot 9$ & $9 \cdot 5$ & $8 \cdot 8,10$ & $0 \cdot 76$ & $0.69,0.83$ & $0 \cdot 48^{\star \star \star}$ \\
\hline & Women & $5 \cdot 4$ & $5 \cdot 0,5 \cdot 8$ & $7 \cdot 3$ & $6 \cdot 8,7 \cdot 9$ & 0.74 & $0 \cdot 68,0 \cdot 80$ & $0 \cdot 46^{\star \star *}$ \\
\hline \multirow[t]{2}{*}{$18: 3 n-3$} & Men & $0 \cdot 87$ & $0.78,0.96$ & $1 \cdot 4$ & $1 \cdot 3,1 \cdot 5$ & 0.62 & $0.56,0.69$ & $0 \cdot 32^{* \star *}$ \\
\hline & Women & 0.67 & $0.62,0.73$ & $1 \cdot 1$ & $1 \cdot 0,1 \cdot 2$ & $0 \cdot 61$ & $0.56,0.67$ & $0.45^{\star \star *}$ \\
\hline \multirow[t]{2}{*}{$20: 5 n-3$} & Men & 0.07 & $0.06,0.08$ & 0.08 & $0 \cdot 06,0 \cdot 10$ & 0.91 & $0 \cdot 74,1 \cdot 10$ & $0.34^{\star \star \star}$ \\
\hline & Women & 0.06 & $0.06,0.07$ & 0.05 & $0.05,0.07$ & $1 \cdot 10$ & $0.96,1.40$ & $0 \cdot 32^{\star \star \star}$ \\
\hline \multirow{2}{*}{$22: 6 n-3$} & Men & $0 \cdot 16$ & $0 \cdot 14,0 \cdot 18$ & $0 \cdot 21$ & $0 \cdot 18,0 \cdot 24$ & $0 \cdot 76$ & $0.65,0.92$ & $0 \cdot 29^{\star \star \star}$ \\
\hline & Women & $0 \cdot 13$ & $0 \cdot 12,0 \cdot 15$ & $0 \cdot 14$ & $0 \cdot 12,0 \cdot 16$ & 0.93 & $0 \cdot 84,1 \cdot 10$ & $0 \cdot 29^{* \star *}$ \\
\hline \multirow[t]{2}{*}{ Total fat $(\mathrm{g} / \mathrm{d})$} & Men & 76 & 70,82 & 81 & 76,87 & 0.94 & $0 \cdot 88,1 \cdot 00$ & $0.59^{\star \star \star}$ \\
\hline & Women & 56 & 53,60 & 62 & 58,66 & 0.90 & $0.85,0.96$ & $0.51^{* \star *}$ \\
\hline \multirow[t]{2}{*}{ Energy (kcal/d) } & Men & 2026 & 1889,2173 & 2103 & 1986, 2227 & 0.96 & $0.90,1.00$ & $0.54^{\star \star \star}$ \\
\hline & Women & 1562 & 1480,1648 & 1591 & 1512,1675 & 0.98 & $0.93,1.00$ & $0.52^{\star \star \star}$ \\
\hline
\end{tabular}

Data are presented as geometric means.

Correlation was significant: ${ }^{\star \star \star} P \leq 0 \cdot 005$.

Table 2 Relative fatty acid intake ( $\mathrm{g} / 100 \mathrm{~g}$ fat) measured by the FFQ and ten repeated $24 \mathrm{~h}$ dietary recalls (24-HDR) in ninety-six men and ninety-nine women from Västerbotten County, northern Sweden

\begin{tabular}{|c|c|c|c|c|c|c|c|c|}
\hline & \multirow[b]{3}{*}{ Gender } & \multicolumn{4}{|c|}{ Relative intake (g/100 g fat) } & & & \multirow{3}{*}{$\begin{array}{c}\text { Spearman correlation } \\
\text { coefficient } \\
\text { FFQ v. } 24-\text { HDR }\end{array}$} \\
\hline & & \multicolumn{2}{|c|}{ FFQ } & \multicolumn{2}{|c|}{ 24-HDR } & \multicolumn{2}{|c|}{ Intake ratio FFQ:24-HDR } & \\
\hline & & Mean & $95 \% \mathrm{Cl}$ & Mean & $95 \% \mathrm{Cl}$ & Mean & $95 \% \mathrm{Cl}$ & \\
\hline \multirow[t]{2}{*}{$14: 0$} & Men & $4 \cdot 7$ & $4 \cdot 5,4 \cdot 9$ & $4 \cdot 7$ & $4 \cdot 5,4 \cdot 9$ & $1 \cdot 00$ & $0.96,1.00$ & $0 \cdot 45^{\star \star \star}$ \\
\hline & Women & $4 \cdot 8$ & $4 \cdot 6,5 \cdot 0$ & $4 \cdot 7$ & $4.5,4.9$ & $1 \cdot 00$ & $0.97,1 \cdot 10$ & $0 \cdot 41^{\star \star \star}$ \\
\hline \multirow[t]{2}{*}{$15: 0$} & Men & $0 \cdot 30$ & $0.27,0.32$ & 0.36 & $0.34,0.38$ & $0 \cdot 83$ & $0 \cdot 76,0.89$ & $0 \cdot 42^{\star \star \star}$ \\
\hline & Women & $0 \cdot 30$ & $0.28,0.33$ & $0 \cdot 36$ & $0.34,0.38$ & $0 \cdot 83$ & $0.77,0.92$ & $0 \cdot 45^{\star \star \star}$ \\
\hline \multirow[t]{2}{*}{$16: 0$} & Men & 21 & 21,21 & 21 & 21,21 & $1 \cdot 00$ & $0.98,1.00$ & $0 \cdot 28^{\star \star}$ \\
\hline & Women & 21 & 21,22 & 21 & 21,21 & 1.00 & $0.99,1.00$ & $0 \cdot 32^{* \star *}$ \\
\hline \multirow[t]{2}{*}{$17: 0$} & Men & 0.17 & $0 \cdot 16,0 \cdot 19$ & 0.21 & $0.20,0.22$ & $0 \cdot 81$ & $0 \cdot 76,0.89$ & $0 \cdot 42^{\star \star \star}$ \\
\hline & Women & $0 \cdot 18$ & $0 \cdot 16,0 \cdot 19$ & $0 \cdot 21$ & $0.20,0.22$ & $0 \cdot 86$ & $0.77,0.92$ & $0 \cdot 45^{\star \star \star}$ \\
\hline \multirow[t]{2}{*}{$18: 2 n-6$} & Men & $9 \cdot 5$ & $8 \cdot 9,10 \cdot 0$ & 12 & 11,12 & 0.79 & $0.76,0.87$ & $0 \cdot 25^{\star}$ \\
\hline & Women & $9 \cdot 6$ & $9 \cdot 1,10 \cdot 0$ & 12 & 11,12 & $0 \cdot 80$ & $0 \cdot 77,0.86$ & $0 \cdot 45^{\star \star \star}$ \\
\hline \multirow[t]{2}{*}{$18: 3 n-3$} & Men & $1 \cdot 1$ & $1 \cdot 1,1 \cdot 2$ & $1 \cdot 7$ & $1 \cdot 7,1 \cdot 8$ & 0.65 & $0.62,0.72$ & $0 \cdot 21^{*}$ \\
\hline & Women & $1 \cdot 2$ & $1 \cdot 1,1 \cdot 3$ & $1 \cdot 8$ & $1 \cdot 7,1 \cdot 8$ & 0.67 & $0.64,0.72$ & $0 \cdot 37^{\star \star \star}$ \\
\hline \multirow[t]{2}{*}{$20: 5 n-3$} & Men & 0.09 & $0 \cdot 09,0 \cdot 10$ & $0 \cdot 10$ & $0 \cdot 08,0 \cdot 12$ & 0.98 & $0 \cdot 79,1 \cdot 20$ & $0 \cdot 33^{\star \star \star}$ \\
\hline & Women & $0 \cdot 11$ & $0 \cdot 10,0 \cdot 12$ & 0.09 & $0.07,0.11$ & $1 \cdot 30$ & $1 \cdot 10,1 \cdot 50$ & $0 \cdot 41^{\star \star \star}$ \\
\hline \multirow[t]{2}{*}{$22: 6 n-3$} & Men & $0 \cdot 21$ & $0 \cdot 19,0 \cdot 24$ & $0 \cdot 25$ & $0 \cdot 22,0.30$ & $0 \cdot 84$ & $0.70,0.98$ & $0 \cdot 30^{\star \star \star}$ \\
\hline & Women & $0 \cdot 24$ & $0.21,0.27$ & $0 \cdot 22$ & $0.19,0.26$ & $1 \cdot 10$ & $0.93,1.20$ & $0 \cdot 42^{\star \star \star}$ \\
\hline
\end{tabular}

Data are presented as geometric means.

Correlation was significant: ${ }^{\star} P \leq 0.05,{ }^{\star \star} P \leq 0.01,{ }^{\star \star \star} P \leq 0.005$.

from 0.23 ( $14: 0$ in men according to the FFQ) to 0.51 (22:6n-3 in women according to the FFQ; Table 3).

\section{Discussion}

The present study evaluates the validity of fatty acid intake estimated by an eighty-four-item semi-quantitative
FFQ used for prospective studies on diet and disease in northern Sweden. Relative to intakes monitored by ten repeated 24-HDR and the fatty acid profile in erythrocyte membranes, the Northern Sweden FFQ was found to be valid for measurement of fish fatty acids $(20: 5 n-3$ and $22: 6 n-3)$ and milk fatty acids (15:0 and $17: 0)$, whereas its validity for fatty acids $18: 2 n-6$ and $18: 3 n-3$, derived mainly from vegetable oils, could not be demonstrated. 
Table 3 Comparison of relative values of fatty acids in erythrocytes (ERY) and fatty acid intakes ( $/ 100 \mathrm{~g}$ fat) measured by the FFQ and ten repeated $24 \mathrm{~h}$ dietary recalls (24-HDR) in eighty-eight men and ninety-two women from Västerbotten County, northern Sweden

\begin{tabular}{|c|c|c|c|c|c|c|c|}
\hline & \multirow[b]{2}{*}{ Gender } & \multicolumn{2}{|c|}{ Erythrocyte membrane fatty acids (\% of total fatty acids) } & \multicolumn{2}{|c|}{ Mean intake ( $\mathrm{g} / 100 \mathrm{~g}$ fat) } & \multicolumn{2}{|c|}{ Spearman correlation coefficient } \\
\hline & & Mean & $95 \% \mathrm{Cl}$ & FFQ & 24-HDR & ERY v. FFQ & ERY v. 24-HDR \\
\hline \multirow[t]{2}{*}{$14: 0$} & Men & 0.61 & $0.59,0.63$ & $4 \cdot 7$ & $4 \cdot 7$ & $0 \cdot 23^{*}$ & $0 \cdot 29^{\star \star \star}$ \\
\hline & Women & 0.63 & $0.60,0.65$ & $4 \cdot 8$ & $4 \cdot 7$ & $0 \cdot 18$ & $0 \cdot 29^{\star \star \star}$ \\
\hline \multirow[t]{2}{*}{$15: 0$} & Men & $0 \cdot 21$ & $0 \cdot 20,0.21$ & $0 \cdot 30$ & $0 \cdot 36$ & $0 \cdot 31^{\star \star \star}$ & $0 \cdot 31^{\star \star \star}$ \\
\hline & Women & 0.22 & $0.21,0.23$ & 0.30 & 0.36 & $0 \cdot 34^{\star \star \star}$ & $0.43^{\star \star \star}$ \\
\hline \multirow[t]{2}{*}{$16: 0$} & Men & 28 & 28,28 & 21 & 21 & -0.02 & $0 \cdot 24^{*}$ \\
\hline & Women & 28 & 28,28 & 21 & 21 & 0.04 & 0.06 \\
\hline \multirow[t]{2}{*}{$17: 0$} & Men & $0 \cdot 40$ & $0.39,0.40$ & $0 \cdot 17$ & $0 \cdot 21$ & $0 \cdot 30^{* \star *}$ & 0.06 \\
\hline & Women & $0 \cdot 40$ & $0.39,0.41$ & $0 \cdot 18$ & $0 \cdot 21$ & $0 \cdot 25^{\star}$ & $0 \cdot 32^{\star \star \star}$ \\
\hline \multirow[t]{2}{*}{$18: 2 n-6$} & Men & 14 & 14,15 & $9 \cdot 5$ & 12 & -0.08 & $0 \cdot 11$ \\
\hline & Women & 15 & 15,15 & $9 \cdot 6$ & 12 & 0.09 & $0 \cdot 13$ \\
\hline \multirow[t]{2}{*}{$18: 3 n-3$} & Men & $0 \cdot 31$ & $0.30,0.33$ & $1 \cdot 1$ & $1 \cdot 7$ & $-0 \cdot 30^{\star \star *}$ & -0.09 \\
\hline & Women & 0.33 & $0.32,0.35$ & $1 \cdot 2$ & $1 \cdot 8$ & $-0 \cdot 12$ & -0.08 \\
\hline \multirow[t]{2}{*}{$20: 5 n-3$} & Men & $1 \cdot 4$ & $1 \cdot 3,1 \cdot 5$ & 0.09 & $0 \cdot 10$ & $0 \cdot 42^{* \star *}$ & $0 \cdot 39^{\star \star \star}$ \\
\hline & Women & $1 \cdot 4$ & $1 \cdot 3,1 \cdot 4$ & $0 \cdot 11$ & 0.09 & $0 \cdot 46^{\star \star \star}$ & $0 \cdot 40^{\star * *}$ \\
\hline \multirow[t]{2}{*}{$22: 6 n-3$} & Men & $5 \cdot 3$ & $5 \cdot 1,5 \cdot 5$ & $0 \cdot 21$ & 0.25 & $0 \cdot 48^{\star \star \star}$ & $0 \cdot 38^{\star \star \star}$ \\
\hline & Women & $5 \cdot 7$ & $5 \cdot 5,5 \cdot 9$ & 0.24 & 0.22 & $0 \cdot 51^{\star \star \star}$ & $0.42^{\star \star \star}$ \\
\hline
\end{tabular}

Data are presented as geometric means.

Correlation was significant: ${ }^{\star} P \leq 0.05,{ }^{* \star *} P \leq 0.005$.

Thus the FFQ is suitable for studies on fatty acids $20: 5 n-3$, $22: 6 n-3,15: 0$ and $17: 0$, and associated food items, in the continuously growing northern Sweden diet cohort, which presently holds nearly 110000 FFQ registrations from the VIP and the northern Sweden MONICA project.

The participants in the present study were selected at random from the study population, and similarities of selected medical and lifestyle markers in the participants and the study population support their representativeness as previously described ${ }^{(11)}$. A weakness of this, as in most dietary studies, is the high proportion with evident underreporting ${ }^{(20)}$. Employing a cut-off for the ratio between total energy intake and BMR corresponding to a value slightly higher than the survival limit when bed-bound, classified $42.7 \%$ and $49.5 \%$ (men and women, respectively) as under-reporters by the FFQ and $55.7 \%$ and $51.5 \%$ by the $24-\mathrm{HDR}^{(11)}$. Notably, the proportions of under-reporters were similar by both the test and the reference method. The problem of under-reporting was met by focusing on ranking of individuals' absolute intake by the two dietary measurement methods and by employing relative intakes ( $\mathrm{g}$ fatty acid/100 $\mathrm{g}$ fat).

The 24-HDR is a commonly used reference method for the validation of dietary intake instruments, although the use of various biomarkers is increasing. Notably, the correlations between fatty acid intakes were stronger between the two intake-monitoring methods than with the erythrocyte fatty acid levels, except for fish fatty acids $20: 5 n-3$ and $22: 6 n-3$ where the associations were virtually similar. The somewhat weaker correlation between the FFQ and 24-HDR measurements for the fish-derived fatty acids is in accordance with the previous finding that the correlation between fish intake monitored by the FFQ and the $24-\mathrm{HDR}$ was weak ${ }^{(11)}$. The overall higher correlations between FFQ and 24-HDR intakes may reflect a closer association of true intakes as these methods measure intake, but it may also reflect that the two methods are affected by correlated systematic errors, as indicated by the similarity in under-reporting. Biomarkers are an advantage in the sense that they are independent, i.e. not subject to the same systematic errors as intake registration. However, biomarkers are still subject to errors. Factors such as sample handling, endogenous synthesis, metabolic transformation, turnover in target tissues, and sensitivity and specificity of the analytical methods, are some issues of biomarkers for diet intake. Thus, theoretically, mainly externally derived fatty acids such as 15:0, 17:0, 18:2n-6 and 18:3n-3, as well as $20: 5 n-3$ and $22: 6 n-3$ with mainly exogenous origin, should be rather good biomarkers of intake, whereas endogenously synthesized fatty acids, such as 16:0, probably should be less useful. Specifically, the fatty acid composition of erythrocyte membranes reflects dietary fat intake over the approximate $120 \mathrm{~d}$ turnover time for erythrocytes $^{(21)}$. This limited time window could theoretically obscure associations with measures reflecting intakes over a year, such as for the FFQ. However, even though day-to-day variations may be considered, the overall eating pattern was quite stable over time in the study group judging from the very high reproducibility found for two FFQ repeated one year apart ${ }^{(11)}$.

\section{4:0, 15:0 and 17:0}

The fatty acids 15:0 and 17:0 are produced by bacteria in the rumen of ruminants, supporting their value as biomarkers for intake of $15: 0$ and 17:0 and milk products. Significant correlations, especially for 15:0, are reported between intake and levels in adipose tissue and serum $^{(22,23)}$. $14: 0$ is also abundant in dairy products and some studies confer 14:0 in adipose tissue, serum 
and erythrocytes a role as a biomarker for milk fat ${ }^{(22,24)}$, but the association may be biased by some endogenous production. Our FFQ measured intakes of 14:0, 15:0 and $17: 0$ correlated well with $24-\mathrm{HDR}$-recorded intakes and also correlated positively and statistically significantly (except for 14:0 in women) with erythrocyte levels. Thus, the FFQ can be used to capture intake of 15:0 and 17:0 and associated food items in the northern Sweden population characterized by consumption of dairy products on a daily basis ${ }^{(11)}$.

\section{6:0}

The fatty acid 16:0 is derived from food, but may also be synthesized endogenously in man ${ }^{(21)}$, which may confound the correlations between intake and levels in human tissues ${ }^{(1,24,25)}$. In contrast to the other fatty acids evaluated in the present study, 16:0 is prevalent in an array of fat-containing foods. Whereas our FFQ-measured absolute intake of 16:0 correlated well with intake measured by the 24-HDR, relative intakes (g/100 g fat) were unrelated. Intake of 16:0 was also unrelated to erythrocyte levels (except for 24-HDR in men). Based on the lack of consistency for the associations between the two ways of evaluating the FFQ-measured intake $v$. 24-HDR (absolute and relative intakes), and because 16:0 is less useful as biomarker, we refrain from drawing a firm conclusion on the validity of the FFQ to measure 16 : 0 intake.

\section{8:2n-6 and 18:3n-3}

The fatty acids $18: 2 n-6$ and $18: 3 n-3$ are exclusively foodderived (essential fatty acids), mainly from vegetable oils, nuts and seeds. This suggests $18: 2 n-6$ and $18: 3 n-3$ as suitable biomarkers, but transformation to longer fatty acids in the same fatty acid series ${ }^{(26)}$, or possible demand for targeted FFQ design, may weaken the associations. Previous studies on intake and content in biological tissues are also contradictory; only studies using targeted FFQ instruments have displayed significant correlations between intake and tissue contents ${ }^{(1,2,23,27)}$, while studies failing to find such associations employed FFQ designed to measure overall intakes ${ }^{(24,25,28)}$. Thus $18: 2 n-6$ and 18:3n-3 levels in biological tissues, such as adipose tissue, erythrocyte membranes or plasma phospholipids, may reflect intake of these fatty acids, but a very carefully designed recording instrument seems to be a prerequisite to estimate intake sufficiently well.

Our FFQ, for which estimated intakes of $18: 2 n-6$ and $18: 3 n-3$ correlated significantly with $24-H D R$ intakes but not with erythrocyte contents, was designed to measure overall dietary intakes. The general design might have been compensated for by a more extensive FFQ, such as reported by Frost Andersen et al. ${ }^{(1)}$, but this was not an option for financial reasons. In addition, the population in northern Sweden predominantly uses margarine for cooking, some butter and only to a smaller extent oils, as in study populations where significant correlations are reported for intake of $18: 2 n-6$ or $18: 3 n-3$ and levels in biological tissues ${ }^{(2,23)}$. Beyond information on intake of margarine, butter and oil, the FFQ did not delineate types of margarines. Due to larger between-product variations, margarines diverge more from average food table values than butter and oils. Furthermore, no specific question was directed towards nuts. Nuts were included in an aggregate with potato chips, cheese doodles and other non-sweet snacks. These limitations have certainly hampered the estimation of $18: 2 n-6$ and $18: 3 n-3$ intakes. The significant negative association between FFQ intake and erythrocyte level for $18: 3 n-3$ in men may to some extent also be explained by a smaller awareness about type and amount of fat consumed by men as compared with women, but is most likely a chance finding.

Given that the FFQ was not designed for optimal estimation of intake of $18: 2 n-6$ and $18: 3 n-3$ fatty acids, it could be expected that the 24-HDR would do so better. However, fats used for cooking were not stressed in the interviews and therefore the lack of significant associations with levels in erythrocytes may relate to the same explanation as the FFQ. We conclude that relative validity of the eighty-four-item FFQ to estimate intake of fatty acids $18: 2 n-6$ and $18: 3 n-3$ could not be demonstrated, which may relate to the need for a more elaborate FFQ instrument or to weakness in the reference methods.

\section{0:5 and 22:6}

The fatty acids $20: 5 n-3$ and $22: 6 n-3$ are derived mainly from dietary sources. Some transformation from 18:3n-3 may occur ${ }^{(19)}$, but there is evidence that the content of $20: 5 n-3$ and $22: 6 n-3$ in erythrocyte membranes ${ }^{(2,3,29,30)}$ can be used as marker for dietary intake. Accordingly, both FFQ and 24-HDR intakes correlated significantly with erythrocyte membrane composition, as well as with each other. Based on these findings and the strong evidence for $20: 5 n-3$ and $22: 6 n-3$ as unbiased biomarkers of intake, we conclude that the FFQ estimates of $20: 5 n-3$ and $22: 6 n-3$ are valid and, consequently, also intake of fatty fish at least. Interestingly, the correlations between erythrocyte levels of $20: 5 n-3$ and $22: 6 n-3$ and dietary intake estimates were higher for the FFQ than for the 24-HDR. This might be explained by the fact that most people in northern Sweden eat fish only a few times weekly or less ${ }^{(11)}$, and intakes therefore may be better monitored by an FFQ monitoring habitual intake than a limited 24-HDR.

\section{FFQ used in the Västerbotten Intervention Project}

The management of the County Council of Västerbotten has decided on shortening the eighty-four-item FFQ version for financial reasons. The shorter version is successively introduced as the longer eighty-four-item copies are running out, and the first participants with a shorter version entered the diet database in 1994. In the shorter sixty-six-item version, frequency alternatives, 
meal size illustrations and selected sections of the FFQ, such as milk, fish and alcohol, are left unchanged. Since the questions on intake of fish and dairy products are identical in the shorter and the longer eighty-four-item FFQ validated in the present study, we suggest that the validity for the fatty acids derived from fish and milk products can be generalized to the shorter version.

\section{Conclusions}

The Northern Sweden eighty-four-item semi-quantitative FFQ evaluated in the present study is suitable for studies on the intake of fish fatty acids (20:5n-3 and 22:6n-3) and milk fatty acids (15:0 and 17:0), such as the prospective diet-disease studies performed in northern Sweden. The conclusion is based on the relative validity compared with intakes recorded on 24-HDR and fatty acid biomarkers as reference methods. In contrast, FFQ estimates of 18:2n-6 and $18: 3 n-3$, mainly derived from vegetable oils, could not be shown to be valid in relation to 24 -HDR or erythrocyte membranes in the present setting.

\section{Acknowledgements}

The authors have no conflicts of interest to report. M.W. contributed to data preparation, analysed and interpreted the data, and participated in drafting and finalizing the manuscript. B.V. carried out the chemical analyses of fatty acids, and participated in data interpretation and finalizing the manuscript. I.J. designed and carried out the study, prepared data, supported in interpretation of the data, and participated in drafting and revision of the manuscript. The study was supported by grants from the Swedish Cancer Society, Västerbotten County Council, the Foundation of Medical Research in Skelleftea and the European Union (Sixth Framework Programme; PHIME; FOOD-CT-2006-016253). The paper reflects only the authors' views; the EU is not liable for any use that may be made of the information. The authors would like to thank Ingvar Bergdahl at the Department of Occupational Medicine for fruitful comments. They also extend special thanks to Wulf Becker at the National Food Administration for valuable opinions and assistance.

\section{References}

1. Andersen LF, Solvoll K, Johansson LR, Salminen I, Aro A \& Drevon CA (1999) Evaluation of a food frequency questionnaire with weighed records, fatty acids, and $\alpha$-tocopherol in adipose tissue and serum. Am J Epidemiol 150, 75-87.

2. Parra MS, Schnaas L, Meydani M, Perroni E, Martinez S \& Romieu I (2002) Erythrocyte cell membrane phospholipid levels compared against reported dietary intakes of polyunsaturated fatty acids in pregnant Mexican women. Public Health Nutr 5, 931-937.

3. Sun Q, Ma J, Campos H, Hankinson SE \& Hu FB (2007) Comparison between plasma and erythrocyte fatty acid content as biomarkers of fatty acid intake in US women. Am J Clin Nutr 86, 74-81.

4. Riboli E \& Kaaks R (1997) The EPIC project: rationale and study design. European Prospective Investigation into Cancer and Nutrition. Int J Epidemiol 26, 6-14.

5. Stegmayr B, Lundberg V \& Asplund K (2003) The events registration and survey procedures in the Northern Sweden MONICA Project. Scand J Public Health 61, Suppl., 9-17.

6. Hallgren CG, Hallmans G, Jansson JH, Marklund SL, Huhtasaari F, Schutz A, Strömberg U, Vessby B \& Skerfving S (2001) Markers of high fish intake are associated with decreased risk of a first myocardial infarction. BrJ Nutr $\mathbf{8 6}$, 397-404.

7. Van Guelpen B, Hultdin J, Johansson I, Hallmans G, Stenling R, Riboli E, Winkvist A \& Palmqvist R (2006) Low folate levels may protect against colorectal cancer. Gut $\mathbf{5 5}$, 1461-1466.

8. Wennberg M, Lundh T, Bergdahl IA, Hallmans G, Jansson JH, Stegmayr B, Custodio HM \& Skerfving S (2006) Time trends in burdens of cadmium, lead and mercury in the population of northern Sweden. Environ Res 100, 330-338.

9. Wennberg M, Bergdahl IA, Stegmayr B, Hallmans G, Lundh T, Skerfving S, Strömberg U, Vessby B \& Jansson JH (2007) Fish intake, mercury, long-chain $n-3$ polyunsaturated fatty acids and risk of stroke in northern Sweden. Br J Nutr $\mathbf{9 8 ,}$ 1038-1045.

10. Gonzales CA, Jakszyn P, Pera G et al. (2006) Meat intake and risk of stomach and esophageal adenocarcinoma within the European Prospective Investigation Into Cancer and Nutrition (EPIC). J Natl Cancer Inst 98, 345-354.

11. Johansson I, Hallmans G, Wikman A, Biessy C, Riboli E \& Kaaks R (2002) Validation and calibration of food-frequency questionnaire measurements in the Northern Sweden Health and Disease cohort. Public Health Nutr 5, 487-496.

12. Weinehall L (1997) Partnership for health. On the role of primary health care in a community intervention programme. Thesis, Umeå University.

13. Wolk A, Vessby B, Ljung H \& Barrefors P (1998) Evaluation of a biological marker of dairy fat intake. Am J Clin Nutr 68, 291-295.

14. Krantzler NJ, Mullen BJ, Schutz HG, Grivetti LE, Holden CA \& Meiselman HL (1982) Validity of telephone diet recalls and records for assessment of individual food intake. $\mathrm{Am} \mathrm{J}$ Clin Nutr 36, 1234-1242.

15. Tran KM, Johnson RK, Soultanakis RP \& Matthews DE (2000) In-person vs telephone-administered multiple-pass 24-hour recalls in women: validation with doubly labeled water. J Am Diet Assoc 100, 777-783.

16. Bergström L (1979) Illustrations of food items. Vår Föda 31, Suppl. 4, 401-403.

17. Håglin L, Hagman U \& Nilsson M (1995) Evaluation of the meal model 'matmallen'. A means of estimating consumed amounts of food. Scand J Nutr 39, 79-83.

18. Wirfalt E, Vessby B, Mattisson I, Gullberg B, Olsson H \& Berglund G (2004) No relations between breast cancer risk and fatty acids of erythrocyte membranes in postmenopausal women of the Malmo Diet Cancer cohort (Sweden). Eur J Clin Nutr 58, 761-770.

19. Burdge GC \& Calder PC (2005) Conversion of $\alpha$-linolenic acid to longer-chain polyunsaturated fatty acids in human adults. Reprod Nutr Dev 45, 581-597.

20. Johansson G, Wikman A, Ahrén AM, Hallmans G \& Johansson I (2001) Underreporting of energy intake in repeated 24-hour recalls related to gender, age, weight status, day of interview, educational level, reported food intake, smoking habits and area of living. Public Health Nutr 4, 919-927.

21. Arab L (2003) Biomarkers of fat and fatty acid intake. J Nutr 133, Suppl. 3, 925S-932S 
22. Wolk A, Furuheim M \& Vessby B (2001) Fatty acid composition of adipose tissue and serum lipids are valid biological markers of dairy fat intake in men. J Nutr 131, 828-833.

23. Baylin A, Kim MK, Donovan-Palmer A, Siles X, Dougherty L, Tocco P \& Campos H (2005) Fasting whole blood as a biomarker of essential fatty acid intake in epidemiologic studies: comparison with adipose tissue and plasma. Am J Epidemiol 162, 373-381.

24. Smedman AE, Gustafsson IB, Berglund LG \& Vessby BO (1999) Pentadecanoic acid in serum as a marker for intake of milk fat: relations between intake of milk fat and metabolic risk factors. Am J Clin Nutr 69, 22-29.

25. Kobayashi M, Sasaki S, Kawabata T, Hasegawa K, Akabane M \& Tsugane S (2001) Single measurement of serum phospholipid fatty acid as biomarker of specific fatty acid intake in middle-aged Japanese men. Eur J Clin Nutr 55, 643-650.

26. Gerster H (1998) Can adults adequately convert $\alpha$-linolenic acid $(18: 3 n-3)$ to eicosapentaenoic acid $(20: 5 n-3)$ and docosahexaenoic acid (22:6n-3)? Int J Vitam Nutr Res 68 159-173.
27. Feunekes GI, Van Staveren WA, De Vries JH, Burema J \& Hautvast JG (1993) Relative and biomarker-based validity of a food-frequency questionnaire estimating intake of fats and cholesterol. Am J Clin Nutr 58, 489-496.

28. Kuriki K, Nagaya T, Tokudome Y, Imaeda N, Fujiwara N, Sato J, Goto C, Ikeda M, Maki S, Tajima K \& Tokudome S (2003) Plasma concentrations of ( $n-3)$ highly unsaturated fatty acids are good biomarkers of relative dietary fatty acid intakes: a cross-sectional study. J Nutr 133, 3643-3650.

29. Godley PA, Campbell MK, Miller C, Gallagher P, Martinson FE, Mohler JL \& Sandler RS (1996) Correlation between biomarkers of omega-3 fatty acid consumption and questionnaire data in African American and Caucasian United States males with and without prostatic carcinoma. Cancer Epidemiol Biomarkers Prev 5, 115-119.

30. Fuhrman BJ, Barba M, Krogh V, Micheli A, Pala V, Lauria R, Chajes V, Riboli E, Sieri S, Berrino F \& Muti P (2006) Erythrocyte membrane phospholipid composition as a biomarker of dietary fat. Ann Nutr Metab 50, 95-102. 